Indignation about the ways in which scientists are dealt with can be accommodated within the framework of seemly EastWest relations only with greater difficulty. The Soviet Government's justification of its treatment of Sakharov is logical enough. That a senior physicist, with such important contributions to the Soviet nuclear weapons programme to his credit, should have lapsed into such outspoken criticism of Soviet military and social policies, is regarded as disloyalty bordering on treachery. That view is consistent with the Leninist adaptation to modern times of the feudal Russian doctrine that people are the property of the state. (Soviet apologists for Sakharov's treatment are forever saying that he remains a member of the Soviet academy, with the appropriate salary, but that is beside the point.) What the Soviet Union appears not to understand is the offence which has been given in the West by its treatment of a distinguished if now dissident scientist which, while falling short of outright imprisonment, deprives the scientific community of such contributions as he may still have to make. (It is, on the other hand, unreasonable that Sakharov and his wife should appear to be asking, in a state whose civil laws restrict the freedom of people to move elsewhere - Helsinki notwithstanding - to be allowed medical treatment in the West.)

President Mitterrand seems to have sensed what these circumstances require with his statement in Moscow last week. There is every reason why lesser mortals should, in lesser ways, follow his example. The case is simply that it is a shabby way to treat a distinguished scientist, however troublesome he may have become, to pack him off to a provincial city out of touch with work, friends and colleagues. To say this when asked, and to volunteer the opinion should opportunity arise, need not cause rancour and may in the long run help Sakharov or at least the principles of civility. Better to seize the opportunity than to spurn it, either from embarrassment or in the belief that huffy silence will miraculously be more effective.

That is the most tricky part of the West's case for restoring East-West scientific relations. Let us hope that President Reagan's rumoured intentions materialize - and that the Soviet Union responds positively. But this time, at the umpteenth time of blowing hot, it is also important that the effort should be seriously intended. Nothing so permanently damages East-West relations as a set of formally negotiated agreements that is then vicariously abandoned because of some unrelated happening. So it would be useful to wring from the US Administration an undertaking that if East-West relations are now to be improved, there will be an understanding that they will not in future be put at hazard for political reasons having nothing to do with science. Although the US State Department has been quietly pragmatic in its administration of US-Soviet collaborations even in the past few difficult years, the simplest way of making sure that programmes now agreed continue is to delegate responsibility for them entirely to the National Academy in Washington which, with egg on its face since Dr Press blew hot, then cold, may be needing a little reassurance.

\section{New exams for old}

\section{Britain's plan to reorganize school examinations is sensible, but should be taken further.}

THE British Secretary of State for Education and Science, Sir Keith Joseph, last week found himself the unaccustomed object of extravagant praise from all quarters of the British educational establishment. The occasion for this achievement, all the more remarkable in the atmosphere of ill-feeling left by strikes by teachers (over pay) in the past few weeks, was Sir Keith's decision finally to end the archaic and unfair two-tier system of examinations for 16-year-olds. For the past thirty-five years, there has been the "O" (for "ordinary") level of the General Certificate of Education (GCE) and, for twenty years, the Certificate of Secondary Education (CSE) for generally less able students. The notion that the two systems should be merged has been promoted for almost as long as they have co-existed. Five years ago, the present government shelved a plan to merge the systems on the grounds that what it called "standards" would be undermined. Sir Keith's conversion to the educationalists' cause is belated, but none the less welcome on that account. The parable of the prodigal son refers. Will the lessons that have been learned, painfully it appears, now be applied elsewhere in the British educational system?

Sir Keith Joseph's scheme will by 1988 do away with the present jungle of 20 separate examination boards administering an astonishing 19,000 syllabuses for 16-year-olds. The confusion they have entailed has brought the whole examination system into disrepute: it is widely known that (for whatever reasons) the standards of some boards are substantially lower than those of others, even when the qualifications awarded are nominally the same. The boards will now be brought together into five groups to administer a single General Certificate of Secondary Education. Examinations under the new scheme will incorporate differentiated papers or questions that will be assessed to nationally-agreed criteria, thus making them applicable over a much wider ability range than the existing examinations. Students will not therefore have to choose - or, more often, be pushed between examinations to which, for reasons of parental pride or teachers' convenience, they are not suited. National grade-related criteria now under development will in principle allow a more objective interpretation of examination results - and are indeed essential if the merger is to succeed. In a skilful compromise that seems to have avoided the inevitable accusation that a change will result in lowered standards, Sir Keith has been able to give an assurance that the performance represented by the three highest grades of the set of seven grades in the new examination will correspond to those of the old " $\mathrm{O}$ " level.

Why has this apparently obvious rationalization taken so long to decide? The British Government has consistently made clear its position that any integration of GCEs and CSEs would have to wait upon an acceptable agreement on national criteria for syllabuses and assessment procedures, and much effort has been expended towards this end by the examinations boards. Despite a few minor hiccups, such as the minister's reluctance at the outset to accept that a physics examination should include some questions on social and economic issues, the draft criteria have won reasonably wide support. (Even so, its draft criteria for biology at 16 includes no explicit reference to the theory of evolution.) What has been achieved shows that a national consensus on core subject content is feasible.

So will Sir Keith stop now that he has brought about his thoroughgoing revision of the national system of examinations at 16 ? The existing advanced level examinations ("A" levels), taken by those who choose to study until 18 , are just as varied and just as much in need of revision, although their faults are different. In an effort to achieve more uniformity of content, nine examinations boards offering "A" levels have put out a document called Common Cores at Advanced Level, but this represents little more than the intersection of the separate syllabuses. And the boards have not yet been able to agree on even this much, with one or other of them declining to accept such-and-such a topic for inclusion. Although the notion that the existing " $\mathrm{A}$ " level examinations provide an education that is too narrow for the important years between 16 and 18 is widely accepted, yet, in the present state of anarchy, it is hard to see where a sensible revision in the direction of more generality could start.

The simplest solution would be to abolish this second tier of examinations. But how then would the universities know which school-leavers are best-suited to be students? That would be the academics' cry. There are two answers: provide a university entrance examination (as, for example, in the United States) and abolish the need for school specialization by not expecting most undergraduates to scamper through a first-degree course in just three years. For most British school-leavers who do not go on to further education, some of the time and effort that would be saved by the elimination of over-specialized teaching in secondary schools could be usefully spent in teaching other modern skills, from driving cars to operating computers. 